\title{
SOCIAL SECURITY PERSONAL-ACCOUNT PARTICIPATION WITH GOVERNMENT MATCHING
}

\author{
Gary V. Engelhardt* \\ Anil Kumar \\ CRR WP 2004-22 \\ Released: October 2004 \\ Draft Submitted: July 2004 \\ Center for Retirement Research at Boston College \\ 550 Fulton Hall \\ 140 Commonwealth Ave. \\ Chestnut Hill, MA 02467 \\ Tel: 617-552-1762 Fax: 617-552-1750 \\ http://www.bc.edu/crr
}

* Gary V. Engelhardt is an associate professor of economics at Syracuse University and a senior research associate at Syracuse's Center for Policy Research. Anil Kumar is an economist in the Research Department at the Federal Reserve Bank of Dallas. All research with the restricted-access data from the Health and Retirement Study was performed under agreement in the Center for Policy Research at Syracuse University. The research reported herein was supported (in part) by the Center for Retirement Research at Boston College pursuant to a grant from the U.S. Social Security Administration. The opinions and conclusions are solely those of the authors and should not be construed as representing the opinions or policy of the Social Security Administration or any agency of the Federal Government, Federal Reserve, Syracuse University or the Center for Retirement Research at Boston College.

(C) 2004, by Gary V. Engelhardt and Anil Kumar. All rights reserved. Short sections of text, not to exceed two paragraphs, may be quoted without explicit permission provided that full credit, including $@$ notice, is given to the source. 


\section{About the Center for Retirement Research}

The Center for Retirement Research at Boston College, part of a consortium that includes parallel centers at the University of Michigan and the National Bureau of Economic Research, was established in 1998 through a grant from the Social Security Administration. The goals of the Center are to promote research on retirement issues, to transmit new findings to the policy community and the public, to help train new scholars, and to broaden access to valuable data sources. Through these initiatives, the Center hopes to forge a strong link between the academic and policy communities around an issue of critical importance to the nation's future.

\section{Center for Retirement Research at Boston College}

550 Fulton Hall

140 Commonwealth Ave.

Chestnut Hill, MA 02467

phone: 617-552-1762 fax: 617-552-1750

e-mail: crr@bc.edu

http://www.bc.edu/crr

Affiliated Institutions:

American Enterprise Institute

The Brookings Institution

Massachusetts Institute of Technology

Syracuse University

Urban Institute 


\begin{abstract}
This paper examines the potential impact of government matching contributions on personal-account participation in the President's Commission on Strengthening Social Security's Model 3 for Social Security reform. Given the government's choice of four plan-design parameters, the magnitude of the match is determined solely by the differential return personal-account assets receive above the notional return, referred to as the "personalaccount premium," akin to the equity premium. The impact of matching on personal-account participation is simulated for older workers (ages 40 to 65) in the first wave of the Health and Retirement Study (HRS) using empirical estimates from a structural model of the impact of employer matching on participation in corporate $401(\mathrm{k})$ plans. For a personal-account premium of five percentage points, which implies a match rate of 12.5 percent for middle- to lower-income workers, the simulations imply that 53 percent of older workers would participate in voluntary personal accounts. The response of participation to matching is very inelastic; it is very unlikely that participation by older workers would achieve the mid-range assumption by the Commission of 67 percent. There is substantial heterogeneity in participation across subsets of older workers: participation would be the lowest for low-educated, minority, and unmarried older workers.
\end{abstract}




\section{Introduction}

The President's Commission on Strengthening Social Security put forth three models for Social Security reform, one of which, Model 3, specified that the federal government would match voluntary personal-account contributions, similar in spirit to what many employers do in corporate $401(\mathrm{k})$ plans. While there have been numerous studies of the role of personal accounts in Social Security reform (Feldstein and Samwick, 2000 and 2002), in affecting retirement (Gustman and Steinmeier, 1998 and 2003), and in specific evaluations and discussions of the Commission's models (Cogan and Mitchell, 2002; Diamond and Orszag, 2002; and Gustman and Steinmeier, 2002), no studies have examined the impact of matching on personal-account participation. This is quite surprising, because the impact of personal accounts on the long-run fiscal position of Social Security depends on the level of participation in these accounts, especially by workers not covered by private pensions. ${ }^{1}$

This paper focuses on the potential impact of government matching in the Commission's Model 3 on personal-account participation. It begins with a mathematical characterization the matching scheme, whereby the individual voluntarily contributes 1 percent of Old Age, Survivors, and Disability Insurance (OASDI) earnings, and, in return, the government matches by re-directing a portion of the payroll tax to the account. Given the government's choice of four plan-design parameters, the magnitude of the match is determined solely by the differential return personal-account assets receive

\footnotetext{
${ }^{1}$ For example, for Model 3, the Commission provided estimates of individual benefits and program fiscal conditions for three personal-account participation rates---0, 67, and 100 percent---and the effect of reform with personal accounts varied: with participation of 67 percent, program cash flow becomes negative four years later, cash flow returns to positive 10 years later, and Trust Fund assets in 2076 are about one-third lower than when participation is 100 percent.
} 
above the notional return, referred to as the "personal-account premium," akin to the equity premium. The impact of matching on personal-account participation is simulated for older workers (ages 40 to 65) in the first wave of the Health and Retirement Study (HRS) using empirical estimates from a structural model of the impact of employer matching on participation in corporate 401(k) plans from a companion paper (Engelhardt and Kumar, 2004). ${ }^{2}$

For a personal-account premium of five percentage points, which implies a match rate of 12.5 percent for middle- to lower-income workers, the simulations imply that 53 percent of older workers would participate in voluntary personal accounts (i.e., contribute one percent of OASDI covered earnings). However, the simulated response of participation to matching is very inelastic with respect to the personal-account premium: for a substantially higher premium of fifteen percentage points, participation would rise to just 54.5 percent. Therefore, it is very unlikely that participation by older workers would achieve the mid-range assumption by the Commission of 67 percent. $^{3}$

In addition, there is substantial heterogeneity in participation across subsets of older workers. There is a large impact of education on participation: for a five percentage-point personal-account premium, 42 percent of high-school dropouts, but 60 percent of those with graduate degrees, would participate. For a five percentage-point personal-account premium, non-whites have simulated participation of 46 percent, which

\footnotetext{
${ }^{2}$ The Commission's Model 3 has three key elements: establishment of personal accounts, changes to traditional Social Security benefits, and transitional general revenue transfers. The paper focuses on the impact of government matching on personal account participation; to keep the analysis on a manageable scale, it does not examine the impact of the other changes proposed in the model. In addition, Model 3 includes a feature whereby voluntary contributions would be subsidized progressively by a refundable tax credit. The Commission's report did not give enough detail as to the structure of that credit in order for us to assess its impact on participation.

${ }^{3}$ Because the HRS only surveys older workers, the conclusions are limited to that segment of the workforce. It is possible that younger workers could have a higher level of participation if there are substantial cohort differences in the responsiveness to matching contributions.
} 
is eight percentage points lower than participation for whites. Non-married individuals have a similar participation gap relative to married individuals. Those with $401(\mathrm{k})$ plans with employer matching are the least likely to participate because employer matching typically would be more generous than government matching, so that $401(\mathrm{k})$ saving would dominate personal-account saving.

The paper is organized as follows. Section II describes government matching contributions under the Commission's Model 3. Section III lays out the structural estimation framework, whereas Section IV summarizes the estimation results in Engelhardt and Kumar (2004). Section V describes the simulation framework and results. There is a brief conclusion.

\section{Matching Under the Commission's Model 3}

Under Model 3, the government would allow the individual to contribute an amount equal to 1 percent of OASDI covered earnings to a personal account. In return, the government would re-direct to the account the lesser of (a) 2.5 percentage points of the 12.4 percent OASDI payroll tax or (b) $\$ 1,000 .{ }^{4}$ The re-directed amount would reach the maximum of $\$ 1,000$ for an individual with $\$ 40,000$ or more in covered earnings; denote this earnings limit as $L^{E}$. The total funds in the account could be invested in a range of financial instruments, and, at the time of claim, benefits on the portion of the account balance derived from the re-directed payroll tax and interest thereon would be offset by "notional" benefits based on the same amount invested at a rate of return defined to be either (1) 250 basis points above the Consumer Price Index (CPI) rate of inflation or (2) 50 basis points below the return on long-term Treasury bonds.

\footnotetext{
${ }^{4}$ The re-direct is assumed to come equally from the employer and employee portions of the tax.
} 
To derive an expression for the government match rate, $m^{V}$, let $Q$ be personalaccount contributions in dollars, $y^{l}$ be gross labor earnings, $y^{S S}$ be covered earnings, where $y^{S S}=\min \left(y^{l}, L^{P}\right)$ and $L^{P}$ is the covered-earnings cap, and $r_{P A}$ be the gross rate of return on personal-account assets. Start with the case in which covered earnings are less than the personal-account earnings limit: $y^{S S}<L^{E}$. Let $\pi$ be the re-directed payroll tax ( $\pi=0.025), q$ be the contribution as a percent of covered earnings $(q=0.01)$, and let $r_{S S}$ be the notional return. Then the annual dollar amount of the match, $M^{V}$, is

$$
M^{V}=\pi y^{S S}\left(1+r_{P A}\right)-\pi y^{S S}\left(1+r_{S S}\right) .
$$

The first term on the right-hand side of (1) is the annual principal and interest on the redirected payroll tax; the second term is the annual notional principal and interest. Equation (1) simplifies to

$$
M^{V}=\pi y^{S S} \Delta r,
$$

where $\Delta r=r_{P A}-r_{S S}$ is the personal-account premium: the extent to which the rate of return in the account exceeds the notional return. To express the dollar match as a rate (i.e., a percentage of contributions), divide both sides of (2) by contributions, $Q=q \cdot y^{S S}$, to yield

$$
m^{V}=\frac{\pi}{q} \Delta r .
$$

Equation (3) shows that the match rate is determined by $\pi$ and $q$, which are plan-design parameters, and $\Delta r$, the personal-account premium. For example, if $\pi=0.025$ and $q=0.01$, then the match rate is $m^{V}=2.5 \Delta r$. If the return on personal-account assets 
exceeds the notional return by 5 percentage points $(\Delta r=0.05)$, then the implicit match rate on the 1 percent voluntary contribution is 0.125 , or 12.5 cents per dollar.

The general formula for the match rate over the entire range of covered earnings is

$$
m^{V}=\frac{\pi}{q} \frac{L^{E}}{\min \left(\max \left(L^{E}, y^{s s}\right), L^{P}\right)} \Delta r .
$$

In the case in which covered earnings are greater than or equal to the earnings limit and less than the covered-earnings cap, $L^{E} \leq y^{s s}<L^{P}$, equation (4) reduces to

$$
m^{V}=\frac{\pi}{q} \frac{L^{E}}{y^{S S}} \Delta r
$$

which means that the match rate declines with covered earnings and, hence, is progressive. If covered earnings are equal to the covered-earnings cap, $y^{s s}=L^{P}$, then (4) reduces to

$$
m^{V}=\frac{\pi}{q} \frac{L^{E}}{L^{P}} \Delta r
$$

Figure 1 plots the match rate by covered earnings if Model 3 were to apply in 2004, where the plan parameters are $\pi=0.025, q=0.01, L^{E}=\$ 40,000$, and $L^{P}=\$ 87,900$, and $\Delta r=0.05$ is assumed. The match rate is 12.5 percent up to $\$ 40,000$ in covered earnings, then falls gradually to 5.7 percent at $\$ 87,900$, the 2004 coveredearnings cap.

\section{The Structural-Estimation Framework}


Although the individual faces an all-or-nothing choice to contribute under Model 3 , it is clear that this personal-account arrangement shares many of the features of corporate 401(k) plans: contributions in pre-tax dollars, matching, inside build-up at the pre-tax rate of return, and a menu of investment options. Because personal accounts do not exist currently, the basic premise in this paper is that the best way to determine the potential impact of government matching is to examine the impact of employer matching in corporate 401(k) plans. Indeed, for those working in jobs without 401(k) coverage, the introduction of personal accounts is akin to the introduction of a 401(k) in terms of the impact on the lifetime opportunity set.

However, to do so requires a departure from the ad hoc reduced-form empirical analysis of the existing literature on $401(\mathrm{k}) \mathrm{s}$ and, instead, the use of structural estimates of the impact of matching on $401(\mathrm{k})$ participation. $^{5}$ In a detailed companion paper that examined the impact of employer matching on 401(k) participation in a structural framework, Engelhardt and Kumar (2004) specified a formal model of optimizing intertemporal behavior and, from the first-order conditions, derived and estimated a structural econometric specification for the relationship between contributions and matching. This section summarizes that framework. The interested reader should see the companion paper (Engelhardt and Kumar, 2004) for a detailed discussion of the theoretical and econometric assumptions.

\footnotetext{
${ }^{5}$ Previous studies employing ad hoc reduced-form empirical analysis include Andrews (1992), Even and Macpherson (1996), EBRI (1994), Papke and Poterba (1995), Clark and Schieber (1998), Bassett, Fleming, and Rodrigues, (1998), Papke (1995), Kusko, Poterba, and Wilcox (1998), Munnell, Sunden, and Taylor (1998), GAO (1997), VanDerhei and Copeland (2001) and Choi, Laibson, Madrian, and Metrick (2002), among others. Although these studies have been valuable contributions to the literature, their estimates are not appropriate to use for analysis of prospective policy changes. To do so requires structural estimates.
} 
Specifically, utility is derived from consumption, $C$, leisure, $l$, depends on a set of demographics, $Z$, and is weakly separable. The consumer lives from the beginning of working life, period 0 , until death in period T. The lifetime is composed of two parts. From period $\tau+1$ to $T$, the consumer is retired and chooses consumption, $C$, to maximize the present value of utility. In retirement, no hours of labor are supplied to the market, so leisure equals the time endowment, $L^{l}$. From period 0 to $\tau$, the consumer works and chooses consumption, leisure, voluntary $401(\mathrm{k})$ contributions, $Q^{401 k}$, and IRA contributions, $Q^{I R A}$, respectively. Wealth is accumulated in five assets: 401(k) wealth, $W^{401 k}$, IRA wealth, $W^{I R A}$, non-401(k) pension wealth, $W^{P}$, other wealth, $W^{A}$, and the present value of Social Security benefits, $W^{S S}$, where total wealth is

$$
W^{T} \equiv W^{401 k}+W^{I R A}+W^{A}+W^{P}+W^{S S} .
$$

Let $\psi\left(W_{\tau}^{T}\right)$ be the expected present value at period $\tau$ of utility for the second part of life, as viewed during the first part of life, and $\rho$ the rate of time preference. When working, the objective function is

$$
\max _{C_{t}, Q_{t}^{011 k}, Q_{t}^{I t A}, l_{t}} \sum_{t=0}^{\tau}(1+\rho)^{-t} U\left(C_{t}, l_{t} ; Z_{t}\right)+(1+\rho)^{-\tau} \psi\left(W_{\tau}^{T}\right),
$$

and the components of wealth evolve as follows

$$
\begin{gathered}
W_{t}^{A}=\left(1+r_{t}\right) W_{t-1}^{A}+w_{t}\left(L^{l}-l_{t}\right)+B_{t}-C_{t}-Q_{t}^{401 k}-Q_{t}^{I R A}-T_{t}, \\
W_{t}^{401 k}=\left(1+r_{t}\right) W_{t-1}^{401 k}+\left(Q_{t}^{401 k}+M_{t}^{V}+R_{t}+M_{t}^{R}\right), \\
W_{t}^{I R A}=\left(1+r_{t}\right) W_{t-1}^{I R A}+Q_{t}^{I R A}, \\
W_{t}^{P}=\left(1+\alpha_{t}^{P}\right) W_{t-1}^{P},
\end{gathered}
$$

and 


$$
W_{t}^{S S}=\left(1+\alpha_{t}^{S S}\right) W_{t-1}^{S S}
$$

In (9), $r_{t}$ is the gross interest rate earned on assets between periods $t-1$ and $t . \quad B_{t}$ is other income, $w_{t}$ is the gross wage rate, and $w_{t}\left(L^{l}-l_{t}\right) \equiv y^{l}$ is labor earnings. In (12) and (13), the non-401(k) (i.e., traditional) pension and Social Security accrual rates, $\alpha^{P}$ and $\alpha^{S S}$, respectively, are functions of age, earnings, and time.

Because some employers mandate 401(k) contributions, let $R$ be the employee's mandatory deferral and $M^{R}$ be the employer's matching contribution in dollars on that deferral. Define $M^{V}$ to be the employer's matching contribution in dollars on the employee's voluntary deferral. The matching functions are

$$
M_{t}^{V}=M^{V}\left(Q_{t}^{401 k}, y_{t}^{l}, m_{t}^{V}\right)
$$

and

$$
M_{t}^{R}=M^{R}\left(R_{t}, y_{t}^{l}, m_{t}^{R}\right),
$$

respectively, are twice continuously differentiable, and $m^{V}$ and $m^{R}$ are vectors of planspecified match rates for voluntary and required $401(\mathrm{k})$ contributions, respectively.

In (9), $T$ is the sum of income and payroll tax liability. It is a twice continuously differentiable function,

$$
T_{t}=f^{T}\left(\theta_{t}^{F}, \theta_{t}^{P} ; I_{t}^{F}, \min \left(y_{t}^{l}, L_{t}^{P}\right)\right)
$$

of a vector of statutory marginal income tax rates, $\theta^{F}$, and FICA and Medicare payroll tax rates, $\theta^{P}$. Federal taxable income is

$$
I_{t}^{F}=\left[\left(y_{t}^{l}-Q_{t}^{401 k}-R_{t}\right)+r_{t} W_{t-1}^{A}-\zeta_{t} Q_{t}^{I R A}\right]-X_{t}-D_{t}
$$

where $X$ is personal exemptions and $D$ is deductions. The factor $\zeta$ is the fraction of IRA contributions that is federally tax-deductible, 


$$
\zeta_{t}=\zeta\left(y_{t}^{l}-Q_{t}^{401 k}-R_{t}+r_{t} W_{t-1}^{A}\right)
$$

IRA deductibility depends on adjusted gross income (AGI), and itself is a function of 401(k) contributions because elective deferrals are excluded from AGI. $L^{P}$ is a vector of covered-earnings caps for payroll taxes.

Sum (9)-(13) to yield the equation of motion for total wealth,

$$
\begin{aligned}
W_{t}^{T}=(1 & \left.+r_{t}\right)\left(W_{t-1}^{A}+W_{t-1}^{401 k}+W_{t-1}^{I R A}\right)+\left(1+\alpha_{t}^{P}\right) W_{t-1}^{P}+\left(1+\alpha_{t}^{S S}\right) W_{t-1}^{S S}+\left(M_{t}^{V}+R_{t}+M_{t}^{R}\right) \\
& +w_{t}\left(L^{l}-l_{t}\right)+B_{t}-C_{t}-T_{t} .
\end{aligned}
$$

Let $\lambda_{t}$ be the multiplier on this constraint. In addition, there is a liquidity constraint, $W_{t}^{A} \geq \xi_{t}$, where $\xi \geq 0$ is an exogenous level of wealth, so that expenditure on consumption, leisure, and tax-deferred saving must be less than or equal to after-tax cash on hand (net of $\xi$ ):

$$
C_{t}+\omega_{t} l_{t}+Q_{t}^{401 k}+Q_{t}^{I R A} \leq-\xi_{t}+\left(1+r_{t}\right) W_{t-1}^{A}+w_{t} L^{l}+B_{t}-T_{t}
$$

Let $\mu_{t}$ be the associated multiplier. In addition, there are minimum- and maximumcontribution constraints on $401(\mathrm{k}) \mathrm{s}$ and IRAs with multipliers in square brackets, respectively,

$$
\begin{array}{lc}
Q_{t}^{401 k} \geq 0, & {\left[\eta_{t}^{0}\right]} \\
Q_{t}^{401 k} \leq L_{t}^{401 k}, & {\left[\eta_{t}^{L}\right]} \\
Q_{t}^{I R A} \geq 0, & {\left[v_{t}^{0}\right]}
\end{array}
$$

and

$$
Q_{t}^{I R A} \leq L_{t}^{I R A} . \quad\left[v_{t}^{L}\right]
$$

The terms $L^{401 k}$ and $L^{I R A}$ are the upper limits on $401(\mathrm{k})$ and IRA contributions, respectively. $\quad L^{I R A}$ is governed by federal law and depends on marital status and pension 
coverage. $L^{401 k}$ is governed by the employer's plan, but may not exceed the federal statutory maximum.

The first-order conditions when working are

$$
\begin{gathered}
U_{C}\left(C_{t}, l_{t} ; Z_{t}\right) \cdot(1+\rho)^{-t}=\lambda_{t}+\mu_{t}, \\
\lambda_{t} \frac{1+M_{Q^{401 k} t}^{V}}{1-T_{I t}\left(1-\zeta_{y^{\prime} t} Q_{t}^{I R A}\right)}+\frac{\eta_{t}^{0}-\eta_{t}^{L}}{1-T_{I t}\left(1-\zeta_{y^{\prime} t} Q_{t}^{I R A}\right)}=\lambda_{t}+\mu_{t}, \\
\lambda_{t} \frac{1}{1-T_{I t} \zeta_{t}}+\frac{v_{t}^{0}-v_{t}^{L}}{1-T_{I t} \zeta_{t}}=\lambda_{t}+\mu_{t},
\end{gathered}
$$

and,

$$
\begin{aligned}
U_{l}\left(C_{t}, l_{t} ; Z_{t}\right) \cdot(1+\rho)^{-t} & =\lambda_{t}\left[w_{t}\left(\alpha_{y^{\prime} t}^{P} W_{t-1}^{P}+\alpha_{y^{l} t}^{S S} W_{t-1}^{S S}+M_{y^{l^{\prime} t}}^{V}+R_{y^{l^{l} t}}+M_{y^{l^{\prime} t}}^{R}\right)\right] \\
& +\left(\lambda_{t}+\mu_{t}\right)\left[w_{t}\left(1-T_{I t}\left(1-R_{y^{\prime} t}-\zeta_{y^{\prime} t} Q_{t}^{I R A}\right)\right)\right]
\end{aligned} .
$$

Note that subscripts indicate a partial derivative (other than $t$, which denotes time); for example, $T_{I}$ is simply the marginal tax rate. Equations (25), (26), (27), and (28) are the first-order conditions for consumption, 401(k) saving, IRA saving, and leisure respectively, where $M_{Q^{401 k}}^{V}$ is the marginal employer match rate for an additional dollar of $401(\mathrm{k})$ contribution, $T_{I}$ is the marginal tax rate, and $\zeta_{y^{\prime}}$ is the change in the fraction of an IRA contribution that is deductible for an additional dollar of AGI.

To derive the econometric model for the structural estimation, let $i$ and $j$ index individuals and 401(k) plans, respectively. Combine (26) and (27) to yield

$$
\lambda_{t} \frac{1+M_{Q^{401 k} t}^{V}}{1-T_{I t}\left(1-\zeta_{y^{\prime} t} Q_{t}^{I R A}\right)}+\frac{\eta_{t}^{0}-\eta_{t}^{L}}{1-T_{I t}\left(1-\zeta_{y^{\prime} t} Q_{t}^{I R A}\right)}=\lambda_{t} \frac{1}{1-T_{I t} \zeta}+\frac{v_{t}^{0}-v_{t}^{L}}{1-T_{I t} \zeta}
$$

multiply both sides of by $1-T_{\text {Iit }}\left(1-\zeta_{y^{\prime} i t} Q_{i t}^{I R A}\right)$, denote 


$$
p_{i j t}^{m}=1+M_{Q^{401 k} i j t}^{V}
$$

as the match price,

$$
p_{i t}^{\tau}=\frac{1-T_{I i t}\left(1-\zeta_{y^{\prime} i t} Q_{i t}^{I R A}\right)}{1-T_{I i t} \zeta_{i t}}
$$

as the relative after-tax price of $401(\mathrm{k})$ to IRA saving, and then rearrange to yield

$$
\eta_{i j t}^{L}-\eta_{i j t}^{0}=\lambda_{i t}\left(p_{i j t}^{m}-p_{i t}^{\tau}\right)+p_{i t}^{\tau}\left(v_{i t}^{L}-v_{i t}^{0}\right)
$$

The left-hand side of (32) represents a latent variable: when $\eta^{L}-\eta^{0}>0$, desired $401(\mathrm{k})$ contributions, $Q^{401 k^{*}}$, exceed the plan limit, $L^{401 k}$, and observed contributions, $Q^{401 k}$, equal the limit; when $\eta^{L}-\eta^{0}=0$, observed 401(k) contributions equal desired contributions; and, finally, when $\eta^{L}-\eta^{0}<0$, desired contributions are less than or equal to zero and observed contributions equal zero. The model uses a two-stage budgeting measure of "full income," so that the first term on the right-hand side of (32) is product of the marginal utility of full income, $\lambda$, and the difference between the match and relative after-tax price of contributing, $\Delta p \equiv p^{m}-p^{\tau}$. Let $V(\omega, y ; \delta)$ denote the intratemporal indirect utility function, in which $\delta$ is a vector of utility function parameters and $\omega$ is the marginal price of leisure,

$$
\omega_{i j t}=w_{i t}\left[1-T_{I_{i t}}\left(1-R_{y^{\prime} i j t}-\zeta_{y^{\prime} i t} Q_{i t}^{I R A}\right)+\left(\alpha_{y^{\prime} i j t}^{P} W_{i j t-1}^{P}+\alpha_{y^{\prime} i t}^{S S} W_{i t-1}^{S S}+M_{y^{\prime} i j t}^{V}+R_{y^{\prime} i j t}+M_{y^{\prime} i j t}^{R}\right)\right] .
$$

Because of the non-linear structure of matching and marginal tax rates, the prices in (32) change depending upon the budget set segment (either because the marginal match rate or tax rate changes). Hence, full income is measured as "virtual" full income, 
$y^{v}$, according to the respective budget segment, with $T^{v}$ the associated tax liability. From (9)-(13) and (19), $y^{v}$ is

$$
y_{i j t}^{v} \equiv-\Delta W_{i t}^{A}+r_{t} W_{i t-1}^{A}+w_{i t} L^{l}+B_{i t}-Q_{i j t}^{401 k}-Q_{i t}^{I R A}-T_{i j t}^{v},
$$

and includes the market value of the leisure endowment. The second term of the righthand side of (32), $v^{L}-v^{0}$, is zero when IRA saving is at an interior solution, positive when constrained by the upper IRA limit, and negative when at the lower IRA limit (of zero). Therefore, express the second term as

$$
\kappa_{i t} \equiv p_{i t}^{\tau}\left(D_{i t}^{L^{R R A}}-D_{i t}^{0}\right),
$$

where $D^{L^{I R A}}$ is a dummy variable that is one if IRA contributions are at the upper limit and zero otherwise, and $D^{0}$ is a dummy variable that is one if IRA contributions are zero and zero otherwise. Substitute the marginal utility of virtual full income, $V_{y}\left(\omega, y^{v} ; \delta\right)$, into (32), let $u$ be an additive term that captures heterogeneity in contribution behavior, then re-write (32) as

$$
Q_{i j t}^{401 k^{*}}=V_{y}\left(\omega_{i t}, y_{i t}^{v} ; \delta\right) \Delta p_{i j t}+\gamma \kappa_{i t}+u_{i j t} .
$$

To keep the index function in the Tobit specification linear in parameters, the model uses functional forms for $V_{y}$ that are linear in utility parameters. In the baseline model,

$$
V_{y}=\delta_{1}+\delta_{2} \omega+2 \delta_{3} y
$$

so that (36) becomes

$$
Q_{i j t}^{401 k^{*}}=\beta_{1} \Delta p_{i j t}+\beta_{2} \omega_{i t} \Delta p_{i j t}+\beta_{3} y_{i t}^{v} \Delta p_{i j t}+\gamma \kappa_{i t}+u_{i j t},
$$


where $\beta_{1}=\delta_{1}, \beta_{2}=\delta_{2}$, and $\beta_{3}=2 \delta_{3}$. If matching raises contributions, then the null hypothesis $\beta_{1}=\beta_{2}=\beta_{3}=0$ should be rejected, and the estimated elasticity of contributions to matching should be positive. The marginal utility of income is allowed to take on other functional forms to check the robustness of the estimates.

Engelhardt and Kumar (2004) used remarkably detailed data from the Health and Retirement Study (HRS), a nationally representative random sample of 51-61 year olds and their spouses (regardless of age) in 1992, to estimate the structural parameters in (38). The HRS asked detailed questions about household income, tax information, wealth, demographics, spousal characteristics, employment, and pensions. A unique feature of these data is that the HRS collected Summary Plan Descriptions (SPDs), which are legal descriptions of pensions written in plain English, from employers of HRS respondents. These descriptions allowed for the measurement of the exact incentives to contribute due to the employer match by using the matching formulas given in the SPD. In addition, the HRS asked respondents' permission to link their survey responses to administrative earnings data from the Social Security Administration (SSA) and the Internal Revenue Service (IRS). These data include covered-earnings' histories from 1951-1991 and W-2 earnings records for jobs held from 1980-1991 and were made available under a restricted-access confidential data agreement with the SSA and IRS, administered by the University of Michigan. In particular, the W-2's provide administrative data on earnings and 401(k) contributions (Cunningham and Engelhardt, 2002). Unlike the contributions data used in previous studies, these data are not subject to measurement error, as they are the employer's official report to the government on annual earnings and elective deferrals. When used with Social Security and pension- 
benefit calculators, the data allowed for the calculation of public and private pension entitlements. Overall, the HRS provides a comprehensive description of the household's financial situation and a significantly richer data source than previous studies.

Because of caps on the generosity of employer matching due to the matching threshold (i.e., the level of contributions at which the match is exhausted), the tax deductibility of contributions, and the graduated rate-and-bracket structure of the income tax, the consumer's budget constraint is non-linear. The kinks in the budget set were smoothed using a non-parametric variant of the differentiable-budget-set methodology of MaCurdy, Green, and Paarsch (1990), based on kernel regression of the combined implicit tax (subsidy) rate from the combination of matching and tax deductibility on AGI over the legally allowable range of $401(\mathrm{k})$ contributions of 0 to $\$ 9500$ using a second-order Gaussian kernel with a bandwidth based on Silverman's rule of thumb, the estimates from which were used to calculate $p^{m}, p^{\tau}$, and $y^{v}$ for each individual in the sample.

The final estimation sample consisted of 1042 individuals from the first wave of the Health and Retirement Study (HRS), who were working in jobs in 1991 and eligible to participate in a 401(k) plan. Descriptive statistics for selected variables used for the estimation are shown in Table 1. Column 1 shows sample means for the full estimation sample, with the standard deviation in parentheses, and the median in square brackets. Overall, the sample consists of mostly white, married individuals in their mid-50s, with some college education and relatively few children at home. Only 56.4 percent of the sample actively participated (defined as having made a positive contribution) in 1991. The sample mean $401(\mathrm{k})$ contribution in calendar year 1991 was $\$ 1,377$, but among 
contributors, the average contribution was $\$ 2,446$ (shown in column 4). A comparison of contributions between those without and with employer matching in columns 2 and 3, respectively, indicates that individuals with matching contributed just over $\$ 400$ more on average than those without matching (i.e., $\$ 1,640-\$ 1,232=\$ 408$ ). The difference in the median contributions between these two groups was $\$ 800$. The average after-tax hourly wage, defined as the gross wage less federal and FICA taxes, was about $\$ 10$ per hour in constant 1991 dollars.

There are three key concerns with the estimation. First, $\omega, y^{v}, \Delta p$, and $\kappa$ in the structural equation (38) all have components based on choice variables and, therefore, are endogenous. Observed $\Delta p$ and $\kappa$ are endogenous because the observed marginal match and tax rates depend upon $401(\mathrm{k})$ and IRA contributions. This is transmitted to the observed $y^{v}$ through the budget-set-smoothing process. In addition, $\omega$ is potentially endogenous, if, for example, individuals with high tastes for saving earn higher wages. To account for endogeneity, a set of instrumental variables based on first-dollar employer match and tax rates for a synthetic individual, which exploit cross-plan variation in matching provisions, were constructed to estimate the parameters in (38) using the Tobitinstrumental-variable estimator of Newey $(1986){ }^{6}$

Second, the generosity of employer matching might be correlated with other firmor individual-level factors that also affect $401(\mathrm{k})$ contributions. For example, columns 2 and 3 in Table 1 indicate that, in plans with employer matching, the individual is much more likely to be able to borrow, direct the investment of plan balances, less likely to have another traditional pension plan, more likely to have the plan annual contribution

\footnotetext{
${ }^{6}$ See Engelhardt and Kumar (2004) for a detailed description of the construction of the instrument set.
} 
limit lower than the federal limit, and more likely to be allowed to make after-tax contributions to the plan, any of which independently might affect contribution behavior. To address this, let $u$ in (38) be composed of two components,

$$
u_{i j t}=\left(\alpha x_{1 i t}+\varepsilon_{i t}\right)+\left(\psi x_{2 j}+v_{j}\right) \text {, }
$$

where $x_{1}$ is a vector of exogenous observable individual characteristics, $\varepsilon$ is a random variable, $\varepsilon \sim N\left(0, \sigma_{\varepsilon}^{2}\right), x_{2}$ is a vector of exogenous observable plan characteristics, and $v$ is a random plan effect, $v \sim N\left(0, \sigma_{v}^{2}\right)$. Then (39) becomes

$$
Q_{i j t}^{401 k^{*}}=\beta_{1} \Delta p_{i j t}+\beta_{2} \omega_{i t} \Delta p_{i j t}+\beta_{3} y_{i t}^{v} \Delta p_{i j t}+\gamma \kappa_{i t}+\alpha x_{1 i t}+\psi x_{2 j}+\varepsilon_{i t}+v_{j} .
$$

To account for individual- and plan-level heterogeneity as flexibly as possible, the specification includes five groups of additional explanatory variables. Specifically, $x_{1}$ includes the following sets of explanatory variables: 1) demographics: dummy variables for married, white, self-reported health status (excellent, very good, good), as well as a quartic in own and spouse's age, education, and spouse's education; 2) risk characteristics and discount rate: dummy variables for risk characteristics described in Barksy, Juster, Kimball, and Shapiro (1998), dummy variables for whether currently smokes, ever smoked, planning horizon, and subjective probabilities of living beyond 75 and 85 , respectively. In addition, $x_{2}$ includes the following explanatory variables: 3 ) fringe benefits offered: dummy variables for whether the firm offers long-term disability and group term life insurance, respectively, as well as the number of health insurance plans, number of retiree health insurance plans, weeks paid vacation, and days of sick pay; 4) other plan characteristics: dummy variables for whether the $401(\mathrm{k})$ allows borrowing, hardship withdrawals, self-directed investment, has an after-tax saving option, 
a 401(k) contribution limit less than the federal limit, respectively, and whether the firm offers other traditional pensions; and, 5) additional employment characteristics: dummy variables for whether the firm offered a retirement seminar, the respondent discussed retirement with co-workers, spousal pension coverage, the spouse's firm offered a retirement seminar, spouse discussed retirement with co-workers, as well as controls for firm size, Census division, and union status.

A final issue is that the estimation sample is likely non-random because it is based on individuals for whom the HRS was able to obtain an employer-provided SPD for the 401(k) plan. The estimation incorporates two exclusion restrictions based on Form 5500 data and uses the selection-corrected Tobit estimator of Vella (1992). The first exclusion is the incidence of pension-plan outsourcing by Census region, employment-size category, one-digit SIC code, and union status (union plan vs. non-union plan) cell in 1992, where outsourcing means the plan was administered by an entity other than the employer. The intuition is that the HRS is less likely to obtain an SPD from the employer if (on average in its cell) plan administration is outsourced, because more than one contact is needed (first the employer, then the plan administrator) to receive the SPD. The second exclusion is the incidence of pension plan consolidation due mergers and acquisitions by cell from 1988-1992. The intuition is that the HRS is less likely either to obtain an SPD from the employer or match it to the employee if (on average in its cell) there has been a lot of plan consolidation, because plan names and detail are often changed upon consolidation. Finally, there are two other exclusions based on HRS data in the selection equation: dummies for whether the individual left the job because the business closed or was laid off, respectively. These help to measure whether the 
employer possibly was in financial difficulty at severance, which, if that resulted in a business failure, would have made it more difficult for the HRS to have obtained an SPD. $^{7}$

\section{Summary of Estimation Results}

With these data and methods, $\beta_{1}, \beta_{2}, \beta_{3}, \gamma, \alpha, \psi, \sigma_{\varepsilon}^{2}$ and $\sigma_{v}^{2}$ in (40) were estimated using the instrumental-variable-random-effects-selection-corrected Tobit maximum likelihood estimator. Columns 1-4 of Table 2, which were excerpted from columns 4-7 of Table 7 in Engelhardt and Kumar (2004), summarize these results and show selected parameter estimates.

The table is organized as follows. Panel A presents the structural parameter estimates for the key explanatory variables in (40) with standard errors in parentheses. ${ }^{8}$ The parameter estimates on the exclusion restrictions in the selection model are shown in Panel B. Panel C lists the set of additional explanatory variables in the models, and Panel D shows the $p$-values for tests of various null hypotheses. Elasticities of 401(k) contributions with respect to the other key variables, evaluated at the sample means, are shown in Panel E of the table, where the method of McDonald and Moffitt (1980) was used to decompose the total elasticity into elasticities along the extensive (participation) and intensive (contributions conditional on participation) margins, respectively.

In column 1, the estimated elasticity of contributions to the match rate is 0.25 (Panel E) and statistically different than zero. About half of the total elasticity occurs

\footnotetext{
7 The construction of the exclusions and the selection equation are discussed in detail in Engelhardt and Kumar (2004).

${ }^{8}$ The standard errors are calculated using the variance-covariance estimator of Newey (1986) with an analytic correction to account for the presence of the estimated selection-correction term in the model.
} 
along the extensive margin and the other half on the intensive margin. ${ }^{9}$ The $p$-value for the test of the null hypothesis that the exclusions do not explain who has a matched SPD is 0.036 , which indicates the exclusions have predictive power for who is in the sample. In particular, greater plan consolidation and business closure significantly decrease the likelihood of having a matched SPD.

The model in column 2 allows for interactions of the demographics and risk and discount rate explanatory variables to allow for a significantly more flexible functional form for $x_{1}$ and $x_{2}$ in (40). The estimated elasticity of contributions to the match rate rises to 0.32 (Panel E). Column 3 shows estimates from a fully interactive model, in which demographics are interacted with the risk and discount rate, fringe benefit, other plan, and additional employment characteristics. The estimated elasticity of contributions to the match rate from this flexible, fully interactive specification is 0.34 (Panel E). Finally, column 4 present estimates from the flexible, fully interactive specification, but in which the marginal utility of income in (37) is quadratic in the net wage and virtual income,

$$
V_{y}=\delta_{1}+\delta_{2} \omega+2 \delta_{3} y+2 \delta_{4} \omega y+3 \delta_{5} y^{2}+\delta_{6} \omega^{2},
$$

and, hence, allows for non-linear effects of the net wage and income on contributions. The estimated elasticity of contributions with respect to the match rate is 0.33 (Panel E) and essentially unchanged. ${ }^{10}$

Overall, the estimation results in Engelhardt and Kumar (2004) suggested that the total elasticity of $401(\mathrm{k})$ contributions with respect to the employer match rate was 0.33 .

\footnotetext{
${ }^{9}$ Engelhardt and Kumar (2004) discussed extensively that these parameter estimates actually conform to theoretically coherent utility-function restrictions.

${ }^{10}$ A number of other specifications were estimated, and, overall, the results were extremely robust. See Engelhardt and Kumar (2004) for details.
} 
The elasticity on the participation margin was 0.17 , which suggests that participation was quite inelastic with respect to the match rate.

\section{Simulating the Impact of Matching under Model 3}

One of the advantages of structural estimation is that the parameter estimates can be used to do policy simulations. This section describes the simulation of the impact of government matching under Model 3 on aggregate personal-account participation for older workers by evaluating the parameter estimates in Table 2 for the full sample of HRS workers, including those not in the estimation sample: individuals in jobs without pension coverage and those with traditional pensions but without $401(\mathrm{k})$ coverage. As argued above, because of the similarities in the two types of saving instruments, the introduction of personal accounts under Model 3 would be akin to the introduction of 401(k) coverage for these two groups of workers.

There are four caveats. First, to keep the analysis on a manageable scale, the simulations do not incorporate the proposed changes to traditional Social Security and the refundable tax credit in the Commission's Model 3; this is beyond the scope of the current paper and is an avenue for further research. Second, the data needed for the structural estimation are so detailed and comprehensive that the HRS is the only dataset appropriate for this type of analysis, but because HRS respondents are composed of a random sample of individuals age 51-61 and their spouses (regardless of age), these simulations best apply to older workers. Specifically, we examine workers in the age 4065 range. Although Model 3 only allowed personal-account contributions until age 55, we included workers up to age 65 , the claiming age for normal benefits under traditional 
Social Security. Therefore, the simulations say little about the anticipated impact of government matching for younger workers. Third, for these simulations to have current policy relevance, older workers today must have the same preferences as older workers in 1991. That is, for comparability, there must be no cohort shifts in preferences toward matching. Finally, private-pension coverage is assumed to be exogenous.

The simulations were parameterized as follows. First, the general formula for the government match rate over the entire range of covered earnings in (4) was used with the following plan parameters: $\pi=0.025, q=0.01, L^{E}=\$ 23,300$, and $L^{P}=\$ 53,400$. The covered-earnings cap of $L^{P}=\$ 53,400$ was chosen rather than $L^{P}=\$ 87,900$ because the former applied in 1991, the year to which the HRS sample applies. The earnings limit for the re-directed payroll tax, $L^{E}=\$ 23,300$, was calibrated to be $\$ 23,000=(\$ 40,000 / \$ 87,900) \cdot \$ 53,400$, i.e., the quotient of the 2004 limits of $L^{E}=\$ 40,000$ and $L^{P}=\$ 87,900$, respectively, multiplied by the 1991 covered-earnings cap of $\$ 53,400$. Second, with those plan parameters fixed, the match rate depends solely on the personal account premium, $\Delta r$ and individual covered earnings, $y^{S S}$. Each sample individual was assigned a grid of values from 0 to 0.20 for $\Delta r$, representing a zero to 20 percentage-point personal-account premium, and, consequently, implied a grid of match rates for that individual's OASDI covered earnings. Third, for each possible match rate for each individual, error terms were randomly drawn from the estimated distributions of $\varepsilon$ and $v$ in (40), respectively. Then the match rate, the individual's actual values of the explanatory variables in (40), and the errors were used to generate a personal-account contribution from the parameter estimates from the preferred structural 
specification in column 3 of Table $2 .{ }^{11} \quad$ Fourth, the individual was defined as "participating" if the contribution was at least one percent of covered earnings. Finally, if the individual was eligible for a $401(\mathrm{k})$ plan that offered employer matching that was more generous than government matching under the personal account, the personal account was deemed the secondary source for tax-deferred saving, whereby desired contributions were allocated first to the 401(k) until the employer match was exhausted and then to the personal account.

Because the simulations require inputs from the fully-specified budget set, including pension-plan details and Social Security and pension entitlements, only individuals who had matched administrative earnings data and were either not in pensioncovered employment or were pension covered and had matched, employer-provided SPDs were included in the simulation sample. This implies that all individuals without matched administrative earnings were excluded, as were individuals with administrative earnings data, in pension-covered employment, but for whom the HRS could not obtain a matched SPD for their pension plan. Therefore, the simulation sample is a selected sample of older workers. In order to make simulated rates of aggregate participation for all older workers, the data in the simulation sample were treated as having come from a stratified-sampling frame with sampling weights equal to the predicted probability of being included in the simulation sample derived from the parameter estimates from the selection equation estimated for the structural estimation in Table 2 (Wooldridge,

\footnotetext{
${ }^{11}$ In order to measure the explanatory variables for $\Delta p$ and $y^{v}$ for individuals not in the estimation sample, the same non-parametric budget-set-smoothing procedure described above was used to construct their budget sets under government matching.
} 
2003). ${ }^{12}$ These weights were multiplied by the HRS household-analysis weight to construct weights for the aggregate analysis. ${ }^{13}$ Overall, there were 6,593 individuals, aged 40-65 and employed in 1991, in the simulation sample, of which 1,042 were 401(k)eligible and in the estimation sample, 2,933 had no pension coverage, and 2,618 were in pension-covered jobs, but had no 401(k). Descriptive statistics for the explanatory variables and the many sub-samples used in the simulations are available upon request.

Figure 2 plots the simulated aggregate personal-account participation versus the personal-account premium. For a premium of five percentage points, which implies a match rate of 12.5 percent for middle- to lower-income workers, the simulations imply that 53 percent of older workers would participate in voluntary personal accounts (i.e., contribute one percent of OASDI covered earnings). However, the simulated response of participation to matching is very inelastic with respect to the premium: for a substantially higher premium of fifteen percentage points, participation would rise to just 54.5 percent. Therefore, it is very unlikely that participation by older workers would achieve the mid-range assumption by the Commission of 67 percent.

Figure 3 shows the same simulation but split according to the age of the worker: under vs. over 55. In particular, Model 3 was designed so that personal-account contributions would be allowed only until age 55. As the figure indicates, an age limit on contributions would have little impact on aggregate participation for older workers. For a

\footnotetext{
${ }^{12}$ Panel B of Table 2 shows the estimates of four parameters from the selection equation---those associated with the exclusion restrictions---the full set of estimates is available from the authors.

${ }^{13}$ The mean of the household-analysis weight implied that the simulation sample represented 9,757,640 older workers. The HRS person-analysis weights are defined only for HRS age-eligible respondents (i.e., ages 51-61 in 1992) and because participation is examined for a broader age range (40-65 in 1991), the household-analysis weights, which are defined for all individuals, were used. The simulation results are not materially different if the person-analysis weights are used and the simulation sample limited to the age-eligible respondents.
} 
personal-account premium of five percentage points, the participation rate would be 52 percent for those under 55, but 53 percent for those over 55 .

While these figures are important for judging the likely aggregate participation rate from the introduction of personal accounts under Model 3, they may mask heterogeneity in participation rates among sub-groups of the population that may be of interest to policy makers. Therefore, Figures $4-7$ show the participation rates for various groups defined by demographic characteristics. There is a large impact on participation associated with education in Figure 4: for a five percentage-point personal-account premium, 42 percent of high-school dropouts would participate, but the education gradient is quite steep, so that 60 percent of those with a graduate degree would participate. Again, it should be emphasized that the differences in participation between education groups are not marginal effects, in which all other characteristics that affect participation were held constant; instead, these represent differences in participation allowing individuals to take on their own characteristics (i.e., their own values for the explanatory variables). Therefore, part of the difference in participation between highschool dropouts and those with graduate degrees in the figure is due to the fact that these groups differ along a number of dimensions in addition to education (e.g., earnings and tax rates).

The same interpretation applies to the remaining figures. Figure 5 shows a substantial difference in participation based on race: for a five percentage-point personalaccount premium, non-whites have simulated participation of 46 percent, which is eight percentage points lower than participation for whites. Figure 6 indicates an almost 10 percentage-point participation gap for non-married relative to married individuals. 
Based on Figure 7, however, there does not appear to be an important difference in projected participation rates between males and females.

Finally, an important determinant of aggregate participation in these accounts is how those individuals without private-pension coverage would respond to government matching. Figure 8 plots the relationship between the account premium and participation for six categories of private-pension coverage, which, roughly speaking, are clustered into three groups in the graph. First, those with 401(k) plans without an employer match, but with a traditional pension, are more likely to participate than any other group. Second, the two groups with the lowest participation---just above 40 percent---would be those in jobs for which they are eligible to make elective deferrals to a 401(k) plan and receive employer matching contributions. Because the typical $401(\mathrm{k})$ has more generous matching than in the personal account, personal accounts would be a secondary source of tax-deferred saving for most of these individuals, which is the primary reason for the low participation for this group. The third group consists of the remaining three pensioncoverage categories, none of which have access to 401(k) saving with matching, and includes those individuals without pension coverage. Individuals in this group would find personal accounts with government matching a marginal source of tax-deferred saving. ${ }^{14}$

\section{Conclusion}

For a personal-account premium of five percentage points, which implies a match rate of 12.5 percent for middle- to lower-income workers, the simulations imply that 53

\footnotetext{
${ }^{14}$ Again, it should be emphasized that the lines in Figure 8 do not represent marginal effects because the participation rates were evaluated using the actual characteristics of each individual in the simulation sample.
} 
percent of older workers would participate. However, the simulated response of participation to matching is very inelastic with respect to the personal-account premium: for a substantially higher personal-account premium of fifteen percentage points, participation would rise to just 54.5 percent.

In addition to those already discussed, there are a number of caveats to these conclusions. First, because the HRS only surveys older workers, conclusions should be limited to that segment of the workforce. It is possible that younger cohorts of workers could have a higher level of participation if there are substantial cohort differences in the responsiveness to matching contributions. Given the complexity of the data construction, estimation, and simulation framework, a parallel analysis of another cohort---for example, the HRS War Baby cohort, born 1942-46---to attempt to isolate cohort changes in the matching elasticities is beyond the scope of this paper, but an interesting avenue for future research. Second, even if preferences are stable across cohorts, the structural estimates effectively are for a particular part of the lifecycle---namely, the years prior to retirement---and it is conceivable that there is intertemporal variation in the responsiveness to matching, so that the annual personal-account participation rates may vary over the lifecycle, even for the same person, and, therefore, the annual participation rates may not yield an accurate estimate of the steady-state lifetime benefits from personal accounts. Third, there were the two important implicit assumptions in the simulations: the introduction of personal accounts would not change lifetime labor supply and the personal-account premium itself was exogenous. With regard to the latter assumption, a key component of most Social Security reforms with personal accounts is (at least some) individual choice over investment assets, so that the return on the account, 
$r_{A}$, and, thus, the premium, $\Delta r$, and the match rate ultimately may be, in part, choice variables.

Finally, the simulations revealed that personal-account participation would be lowest among groups some policymakers deem to be the most vulnerable: non-married, minority, and lesser educated. However, there is a distinction between personal-account wealth and retirement wealth. In particular, households may reduce saving in other forms upon the introduction of the accounts, and to the extent that this saving offset is greater for those groups with the highest account participation---married, white, and highly educated---the net effect on retirement income security might not differ for the more relative to the less vulnerable. Unfortunately, there is substantial debate about the extent of the pension-saving offset, and there are no studies that estimate this offset for all of the demographic categories in this analysis. ${ }^{15}$ This is an avenue for future research.

\footnotetext{
${ }^{15}$ Gale (1998) found that the pension-saving offset was larger for the college-educated.
} 


\section{References}

Andrews, Emily S., "The Growth and Distribution of 401(k) Plans," in Trends in Pensions 1992, John A. Turner and Daniel J. Beller, eds. (Washington, DC: U.S. Department of Labor) 1992, pp. 149-176.

Barksy, Robert B., F. Thomas Juster, Miles S. Kimball, and Matthew D. Shapiro, "Preference Parameters and Behavioral Heterogeneity: An Experimental Approach in the Health and Retirement Study," Quarterly Journal of Economics 112:2 (1998): 537-580.

Bassett, William F., Michael J. Fleming, and Anthony P. Rodrigues, "How Workers Use 401(k) Plans: The Participation, Contribution, and Withdrawal Decisions,", National Tax Journal 51:2 (1998): 263-289.

Choi, James J., David Laibson, Brigitte C. Madrian, and Andrew Metrick, "Defined Contribution Pensions: Plan Rules, Participant Decisions, and the Path of Least Resistance," in James M. Poterba, ed., Tax Policy and the Economy, Vol. 16 (Cambridge, MA: MIT Press), 2002.

Clark, Robert L. and Sylvester J. Schieber, "Factors Affecting Participation Rates and Contribution Levels in 401(k) Plans," in Living with Defined Contribution Pensions: Remaking Responsibility for Retirement, Olivia S. Mitchell and Sylvester J. Schieber, eds. (Philadelphia: University of Pennsylvania Press), 1998, pp. 69-97.

Cogan, John F., and Olivia S. Mitchell, "The Role of Economic Policy in Social Security Reform: Economic Perspectives from the President's Commission," NBER Working Paper No. 9166, 2002.

Commission on Strengthening Social Security, "Strengthening Social Security and Creating Wealth for All Americans," Final Report, 2001.

Cunningham, Christopher R., and Gary V. Engelhardt, "Federal Tax Policy, Employer Matching, and 401(k) Saving: Evidence from HRS W-2 Records," National Tax Journal, 2002.

Diamond, Peter A., and Peter R. Orszag, "An Assessment of the Proposals of the President's Commission to Strengthen Social Security," NBER Working Paper No. 9097, 2002.

Employee Benefit Research Institute, Salary Reduction Plans and Individual Saving for Retirement, Issue Brief No. 155 (Washington, DC: Employee Benefit Research Institute), 1994. 
Engelhardt, Gary V., and Anil Kumar, "Employer Matching and 401(k) Saving: Evidence from the Health and Retirement Study," Mimeo., Syracuse University, 2003.

Even, William E., and David A. Macpherson, "Factors Influencing Employee Participation in 401(k) Plans," Mimeo, Miami University (Ohio), 1996.

Feldstein, Martin, and Andrew Samwick, "Allocating Payroll Tax Revenue to Personal Retirement Accounts to Maintain Social Security Benefits and the Payroll Tax Rate,” NBER Working Paper No. 7767, 2000.

Feldstein, Martin, and Andrew Samwick, "Potential Paths of Social Security Reform," in James M. Poterba, ed., Tax Policy and the Economy 16 (2002) (Cambridge, MA: MIT Press), 181-224.

Gale, William G., "The Effects of Pensions on Household Wealth: A Re-Evaluation of Theory and Evidence," Journal of Political Economy 106 (1998): 706-723.

General Accounting Office, "401(k) Pension Plans: Loan Provisions Enhance Participation But May Affect Income Security for Some," Report GAO/HEHS98-5, 1997.

Gustman, Alan L., and Thomas L. Steinmeier, "Privatizing Social Security: First-Round Effects of a Generic, Voluntary, Privatized U.S. Social Security System," in Martin Feldstein, ed., Privatizing Social Security (Chicago, IL: University of Chicago Press), 1998, 313-357.

Gustman, Alan L., and Thomas L. Steinmeier, "The New Social Security Commission Personal Accounts: Where is the Investment Principal?," NBER Working Paper No. 9045, 2002.

Gustman, Alan L., and Thomas L. Steinmeier, "Retirement Effects of Proposals by the President's Commission to Strengthen Social Security," NBER Working Paper No. 10030, 2003.

Kusko, Andrea, James M. Poterba, and David Wilcox, "Employee Decisions With Respect to 401(k) Plans," in Living with Defined Contribution Pensions: Remaking Responsibility for Retirement, Olivia Mitchell and Sylvester Schieber, eds. (Philadelphia: University of Pennsylvania Press) 1998, pp. 98-112.

MaCurdy, Thomas E., David Green, and Harry Paarsch, "Assessing Empirical Approaches for Analyzing Taxes and Labor Supply," Journal of Human Resources 25 (Summer 1990): 415-90.

McDonald, John F., and Robert A. Moffitt, "The Uses of Tobit Analysis," Review of Economics and Statistics 62 (1980): 318-321. 
Munnell, Alicia H., Annika Sunden, and Catherine Taylor, "What Determines 401(k) Participation and Contributions?” Mimeo., Boston College, 2001.

Newey, Whitney K., "Linear Instrumental Variable Estimation of Limited Dependent Variable Models with Endogenous Explanatory Variables," Journal of Econometrics 32 (1986): 127-141.

Papke, Leslie E., "Participation in and Contributions to 401(k) Pension Plans: Evidence from Plan Data," Journal of Human Resources 30:2 (1995): 311-325.

Papke, Leslie E., Poterba, James M, "Survey Evidence on Employer Match Rates and Employee Saving Behavior in 401(k) Plans", Economics Letters 49, 313-317, 1995.

Wooldridge, Jeffrey, M., "Inverse Probability Weighted Estimation for General Missing Data Problems," Mimeo., Michigan State University, 2003.

Vanderhei, Jack, and Craig Copeland, "A Behavioral Model for Predicting Employee Contributions to 401(k) Plans: Preliminary Results," North American Actuarial Journal 5:1 (2001): 80-94.

Vella, Francis, "Simple Tests for Sample Selection Bias in Censored and Discrete Choice Models," Journal of Applied Econometrics 7:4 (1992): 412-421. 
Table 1. Sample Means of Selected Variables in the Estimation Sample, Standard Deviations in Parentheses, Medians in Square Brackets

\begin{tabular}{|c|c|c|c|c|c|}
\hline & (1) & (2) & (3) & (4) & (5) \\
\hline Variable & Full Sample & $\begin{array}{l}\text { Subsample } \\
\text { without } \\
\text { Matches }\end{array}$ & $\begin{array}{c}\text { Subsample } \\
\text { with Matches }\end{array}$ & $\begin{array}{l}\text { Subsample with } \\
\text { Positive } \\
\text { Contributions }\end{array}$ & $\begin{array}{c}\text { Subsample } \\
\text { with Zero } \\
\text { Contributions }\end{array}$ \\
\hline $\begin{array}{l}\text { 401(k) Contributions (in } \\
1991 \text { dollars) }\end{array}$ & $\begin{array}{c}1377 \\
(1920) \\
{[500]}\end{array}$ & $\begin{array}{c}1232 \\
(1895) \\
{[100]}\end{array}$ & $\begin{array}{c}1640 \\
(1938) \\
{[900]}\end{array}$ & $\begin{array}{l}2446 \\
(1982) \\
{[1892]}\end{array}$ & $\begin{array}{c}0 \\
(0) \\
{[0]}\end{array}$ \\
\hline Match Rate (in percent) & $\begin{array}{c}23 \\
(37) \\
{[0]}\end{array}$ & $\begin{array}{c}0 \\
(0) \\
{[0]}\end{array}$ & $\begin{array}{c}65 \\
(32) \\
{[50]}\end{array}$ & $\begin{array}{c}28 \\
(38) \\
{[0]}\end{array}$ & $\begin{array}{c}17 \\
(33) \\
{[0]}\end{array}$ \\
\hline $\begin{array}{l}\text { After-Tax Wage } \\
\text { (in 1991 dollars per hour) }\end{array}$ & $\begin{array}{l}10.04 \\
(5.55) \\
{[8.92]}\end{array}$ & $\begin{array}{l}10.09 \\
(5.56) \\
{[9.12]}\end{array}$ & $\begin{array}{l}9.96 \\
(5.54) \\
{[8.51]}\end{array}$ & $\begin{array}{l}10.91 \\
(5.96) \\
{[9.66]}\end{array}$ & $\begin{array}{c}8.91 \\
(4.75) \\
{[8.23]}\end{array}$ \\
\hline Age (years) & $\begin{array}{l}54.9 \\
(5.2) \\
{[55.0]}\end{array}$ & $\begin{array}{l}54.9 \\
(5.1) \\
{[55.0]}\end{array}$ & $\begin{array}{l}54.8 \\
(5.4) \\
{[55.0]}\end{array}$ & $\begin{array}{l}54.7 \\
(5.0) \\
{[55.0]}\end{array}$ & $\begin{array}{l}55.1 \\
(5.5) \\
{[55.0]}\end{array}$ \\
\hline Education (years) & $\begin{array}{c}13.3 \\
(2.7) \\
{[13.0]}\end{array}$ & $\begin{array}{c}13.5 \\
(2.7) \\
{[13.0]}\end{array}$ & $\begin{array}{c}13.0 \\
(2.6) \\
{[12.0]}\end{array}$ & $\begin{array}{c}13.8 \\
(2.5) \\
{[14.0]}\end{array}$ & $\begin{array}{c}12.7 \\
(2.7) \\
{[12.0]}\end{array}$ \\
\hline Percent Female & 47 & 47 & 47 & 48 & 45 \\
\hline Percent White & 82 & 81 & 85 & 86 & 78 \\
\hline Number of Dependents & $\begin{array}{c}0.70 \\
(0.93) \\
{[0.0]}\end{array}$ & $\begin{array}{c}0.68 \\
(0.93) \\
{[0.0]}\end{array}$ & $\begin{array}{c}0.75 \\
(0.94) \\
{[0.0]}\end{array}$ & $\begin{array}{c}0.71 \\
(0.95) \\
{[0.0]}\end{array}$ & $\begin{array}{c}0.70 \\
(0.91) \\
{[0.0]}\end{array}$ \\
\hline Percent Married & 80 & 79 & 82 & 81 & 79 \\
\hline $\begin{array}{l}\text { Spouse's Education } \\
\text { (Years) }\end{array}$ & $\begin{array}{l}10.6 \\
(5.5) \\
{[12.0]}\end{array}$ & $\begin{array}{l}10.6 \\
(5.7) \\
{[12.0]}\end{array}$ & $\begin{array}{l}10.6 \\
(5.2) \\
{[12.0]}\end{array}$ & $\begin{array}{l}11.0 \\
(5.5) \\
{[12.0]}\end{array}$ & $\begin{array}{l}10.1 \\
(5.5) \\
{[12.0]}\end{array}$ \\
\hline $\begin{array}{l}\text { Percent with Plans that } \\
\text { Allow Borrowing }\end{array}$ & 36 & 19 & 68 & 42 & 29 \\
\hline $\begin{array}{l}\text { Percent with Plans that } \\
\text { Allow Hardship } \\
\text { Withdrawals }\end{array}$ & 4 & 4 & 5 & 6 & 2 \\
\hline
\end{tabular}




\begin{tabular}{|c|c|c|c|c|c|}
\hline Variable & Full Sample & $\begin{array}{c}\text { Subsample } \\
\text { without } \\
\text { Matches }\end{array}$ & $\begin{array}{c}\text { Subsample } \\
\text { with Matches }\end{array}$ & $\begin{array}{c}\text { Subsample } \\
\text { with Positive } \\
\text { Contributions }\end{array}$ & $\begin{array}{c}\text { Subsample } \\
\text { with Zero } \\
\text { Contributions }\end{array}$ \\
\hline $\begin{array}{l}\text { Percent with Plans that } \\
\text { Allow Self-Directed } \\
\text { Investment }\end{array}$ & 63 & 46 & 92 & 66 & 58 \\
\hline $\begin{array}{l}\text { Percent with Other } \\
\text { Pensions at the Firm }\end{array}$ & 47 & 53 & 34 & 45 & 48 \\
\hline $\begin{array}{l}\text { Percent with Plan Limit } \\
\text { less than Federal Limit }\end{array}$ & 80 & 73 & 92 & 76 & 85 \\
\hline $\begin{array}{l}\text { Percent with Plan that } \\
\text { Allows After-Tax Saving }\end{array}$ & 23 & 9 & 47 & 26 & 18 \\
\hline $\begin{array}{l}\text { Percent that had } \\
\text { Employer-Sponsored } \\
\text { Retirement Seminar }\end{array}$ & 23 & 23 & 23 & 25 & 20 \\
\hline $\begin{array}{l}\text { Percent with a Spouse } \\
\text { who has a Pension }\end{array}$ & 39 & 39 & 38 & 42 & 35 \\
\hline Percent in a Union & 34 & 39 & 27 & 28 & 43 \\
\hline Number of Observations & 1042 & 672 & 370 & 588 & 454 \\
\hline
\end{tabular}


Table 2. Selection-Corrected Instrumental-Variable Structural Parameter Estimates of 401(k) Contributions for Selected Variables, Standard Errors in Parentheses

\begin{tabular}{|c|c|c|c|c|}
\hline & (1) & (2) & (3) & (4) \\
\hline Explanatory Variable & $\begin{array}{l}\text { IV Tobit } \\
\text { with } \\
\text { Selection }\end{array}$ & $\begin{array}{l}\text { IV Tobit } \\
\text { with } \\
\text { Selection }\end{array}$ & $\begin{array}{l}\text { IV Tobit } \\
\text { with } \\
\text { Selection }\end{array}$ & $\begin{array}{l}\text { IV Tobit } \\
\text { with } \\
\text { Selection }\end{array}$ \\
\hline \multicolumn{5}{|l|}{ A. Structural Parameter Estimates } \\
\hline$\Delta p$ & $\begin{array}{l}-160.070 \\
(946.512)\end{array}$ & $\begin{array}{c}258.672 \\
(833.141)\end{array}$ & $\begin{array}{c}163.954 \\
(927.813)\end{array}$ & $\begin{array}{l}-1195.253 \\
(1960.801)\end{array}$ \\
\hline$\omega \Delta p$ & $\begin{array}{l}130.295 \\
(31.133)\end{array}$ & $\begin{array}{l}151.056 \\
(35.709)\end{array}$ & $\begin{array}{l}148.177 \\
(32.801)\end{array}$ & $\begin{array}{c}259.458 \\
(124.278)\end{array}$ \\
\hline$y^{v} \Delta p$ & $\begin{array}{l}-123.042 \\
(354.787)\end{array}$ & $\begin{array}{l}-295.120 \\
(322.003)\end{array}$ & $\begin{array}{l}-231.164 \\
(306.290)\end{array}$ & $\begin{array}{c}302.933 \\
(925.265)\end{array}$ \\
\hline$\omega y^{v} \Delta p$ & --- & --- & --- & $\begin{array}{c}1.085 \\
(67.432)\end{array}$ \\
\hline$y^{v 2} \Delta p$ & --- & --- & --- & $\begin{array}{l}-29.661 \\
(30.653)\end{array}$ \\
\hline$\omega^{2} \Delta p$ & --- & --- & --- & $\begin{array}{l}-1.476 \\
(1.943)\end{array}$ \\
\hline$\kappa$ & $\begin{array}{c}228.264 \\
(1040.203)\end{array}$ & $\begin{array}{c}-229.667 \\
(1168.486)\end{array}$ & $\begin{array}{c}4.665 \\
(1106.508)\end{array}$ & $\begin{array}{l}-2110.099 \\
(1767.221)\end{array}$ \\
\hline Selections Term in Contribution Tobit & $\begin{array}{l}-3262.9 \\
(866.1)\end{array}$ & $\begin{array}{c}-3307.8 \\
(837.9)\end{array}$ & $\begin{array}{c}-3632.8 \\
(846.9)\end{array}$ & $\begin{array}{c}-2839.6 \\
(822.2)\end{array}$ \\
\hline
\end{tabular}




\begin{tabular}{|c|c|c|c|c|}
\hline & $(1)$ & (2) & (3) & (4) \\
\hline $\begin{array}{l}\text { Selection-Equation Exclusions: } \\
\text { Plan Administration Outsourcing }\end{array}$ & $\begin{array}{l}-0.026 \\
(0.021)\end{array}$ & $\begin{array}{l}-0.028 \\
(0.021)\end{array}$ & $\begin{array}{l}-0.023 \\
(0.021)\end{array}$ & $\begin{array}{l}-0.030 \\
(0.021)\end{array}$ \\
\hline Plan Consolidation & $\begin{array}{l}-0.050 \\
(0.029)\end{array}$ & $\begin{array}{l}-0.055 \\
(0.030)\end{array}$ & $\begin{array}{l}-0.053 \\
(0.030)\end{array}$ & $\begin{array}{l}-0.076 \\
(0.029)\end{array}$ \\
\hline Left Job Due to Business Closure & $\begin{array}{l}-0.035 \\
(0.014)\end{array}$ & $\begin{array}{l}-0.033 \\
(0.014)\end{array}$ & $\begin{array}{l}-0.032 \\
(0.014)\end{array}$ & $\begin{array}{l}-0.027 \\
(0.013)\end{array}$ \\
\hline Left Job Because Laid Off & $\begin{array}{l}-0.007 \\
(0.018)\end{array}$ & $\begin{array}{l}-0.008 \\
(0.018)\end{array}$ & $\begin{array}{l}-0.010 \\
(0.018)\end{array}$ & $\begin{array}{l}-0.015 \\
(0.018)\end{array}$ \\
\hline $\begin{array}{l}p \text {-Value for Test of Joint } \\
\text { Significance of Exclusions }\end{array}$ & 0.036 & 0.037 & 0.048 & 0.012 \\
\hline C. Controls & & & & \\
\hline $\begin{array}{l}\text { Demographics, Discount Rate, Fringe } \\
\text { Benefit, and Plan Characteristics? }\end{array}$ & Yes & Yes & Yes & Yes \\
\hline $\begin{array}{l}\text { Other Employment Characteristics? } \\
\text { Interactions of Demographics and } \\
\text { Discount Rate? }\end{array}$ & $\begin{array}{l}\text { Yes } \\
\text { No }\end{array}$ & $\begin{array}{l}\text { Yes } \\
\text { Yes }\end{array}$ & $\begin{array}{l}\text { Yes } \\
\text { Yes }\end{array}$ & $\begin{array}{l}\text { Yes } \\
\text { Yes }\end{array}$ \\
\hline $\begin{array}{l}\text { Interactions of Demographics with } \\
\text { Discount Rate, Fringe, Plan, and } \\
\text { Other Employment Characteristics? }\end{array}$ & No & No & Yes & Yes \\
\hline D. $p$-Values for Tests of Hypotheses & & & & \\
\hline Match Rate Has No Effect & 0.00009 & 0.00009 & 0.00009 & 0.00020 \\
\hline Net Wage Has No Effect & 0.00009 & 0.00009 & 0.00009 & 0.00080 \\
\hline Full Income Has No Effect & 0.72870 & 0.35940 & 0.45040 & 0.51280 \\
\hline $\begin{array}{l}\text { Relative After-Tax Price Has No } \\
\text { Effect }\end{array}$ & 0.00009 & 0.00009 & 0.00009 & 0.00009 \\
\hline
\end{tabular}


E. Instrumental Variable Tobit Elasticity with Respect to (2) (3) (4)

Match Rate

Full Income

Net Wage

Relative After-Tax Price of 401(k)

Match Rate

Full Income

Net Wage

Relative After-Tax Price of 401(k)

\section{Match Rate}

Full Income

Net Wage

Relative After-Tax Price of 401(k)

\begin{tabular}{|c|c|c|c|}
\hline \multicolumn{4}{|c|}{ Total } \\
\hline 0.25 & 0.32 & 0.34 & 0.33 \\
\hline$(0.10)$ & $(0.09)$ & $(0.10)$ & $(0.11)$ \\
\hline-0.04 & -0.09 & -0.07 & 0.05 \\
\hline$(0.11)$ & $(0.10)$ & $(0.10)$ & $(0.19)$ \\
\hline 0.44 & 0.50 & 0.52 & 0.55 \\
\hline$(0.10)$ & $(0.11)$ & $(0.11)$ & $(0.20)$ \\
\hline-0.63 & -0.72 & -0.79 & -0.56 \\
\hline$(0.22)$ & $(0.20)$ & $(0.20)$ & $(0.20)$ \\
\hline \multicolumn{4}{|c|}{ On the Extensive Margin } \\
\hline 0.13 & 0.17 & 0.17 & 0.19 \\
\hline$(0.05)$ & $(0.04)$ & $(0.05)$ & $(0.06)$ \\
\hline-0.02 & -0.05 & -0.04 & 0.03 \\
\hline$(0.05)$ & $(0.05)$ & $(0.05)$ & $(0.11)$ \\
\hline 0.23 & 0.26 & 0.27 & 0.31 \\
\hline$(0.06)$ & $(0.06)$ & $(0.06)$ & $(0.11)$ \\
\hline-0.33 & -0.38 & -0.39 & -0.31 \\
\hline$(0.12)$ & $(0.11)$ & $(0.10)$ & $(0.12)$ \\
\hline \multicolumn{4}{|c|}{ On the Intensive Margin } \\
\hline 0.12 & 0.16 & 0.16 & 0.15 \\
\hline$(0.05)$ & $(0.05)$ & $(0.05)$ & $(0.05)$ \\
\hline-0.02 & -0.04 & -0.04 & 0.02 \\
\hline$(0.05)$ & $(0.05)$ & $(0.05)$ & $(0.08)$ \\
\hline 0.16 & 0.24 & 0.25 & 0.24 \\
\hline$(0.05)$ & $(0.06)$ & $(0.06)$ & (0.09) \\
\hline-0.30 & -0.35 & -0.39 & -0.24 \\
\hline$(0.10)$ & $(0.10)$ & $(0.10)$ & (0.09) \\
\hline
\end{tabular}

Note: Excerpted from columns 4-7 of Table 7 in Engelhardt and Kumar (2004). Columns 1-3 of Panel A of this table present parameter estimates for the first four terms in equation (40) in the text for linear marginal utility of income. Column 4 presents estimates for quadratic marginal utility of income, as shown in the text. For all columns, the sample consists of 1042 individuals, and the upper contributions limits are individualvarying, as described in the text. All columns assume prices, net wage, and virtual income are endogenous, 
and the IV-Tobit estimator of Newey (1986) is used. All columns present selection-corrected estimates using the exclusion restrictions discussed. The parameter estimates for the selection term in the structural contributions Tobit are shown in Panel B. Panel B also presents parameter estimates for the exclusion restrictions from the selection equations. The estimates in column 3 are not selection-corrected. Panels $\mathrm{C}$ and $\mathrm{D}$ present the controls included and the results from hypothesis tests, respectively. Panel E presents estimates of elasticities of 401(k) contributions based on the structural parameter estimates in panel A, evaluated at the sample means. The elasticities on the extensive and intensive margins were calculated using the McDonaldMoffitt (1980) decomposition, respectively. 
Figure 1. Implied Match Rate by Earnings for an Account Premium of 5 Percent

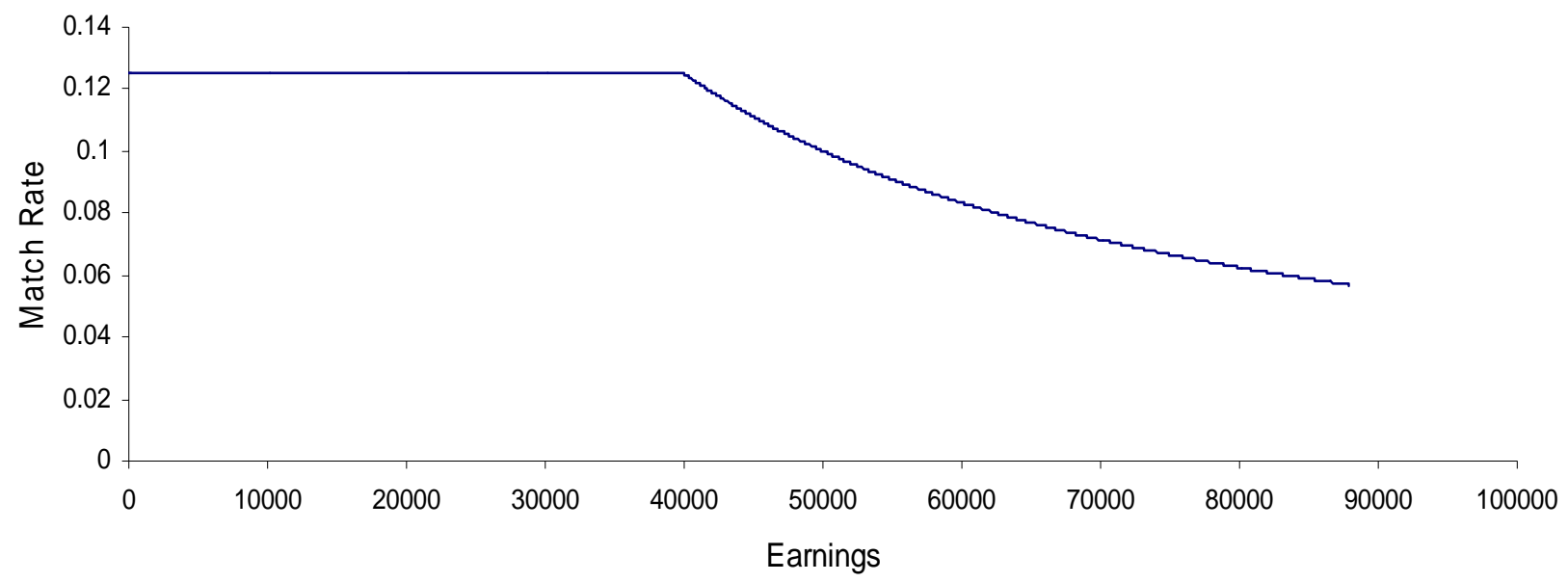


Figure 2. Impact of Account Premium on Aggregate

Participation, All Workers Ages 40-65

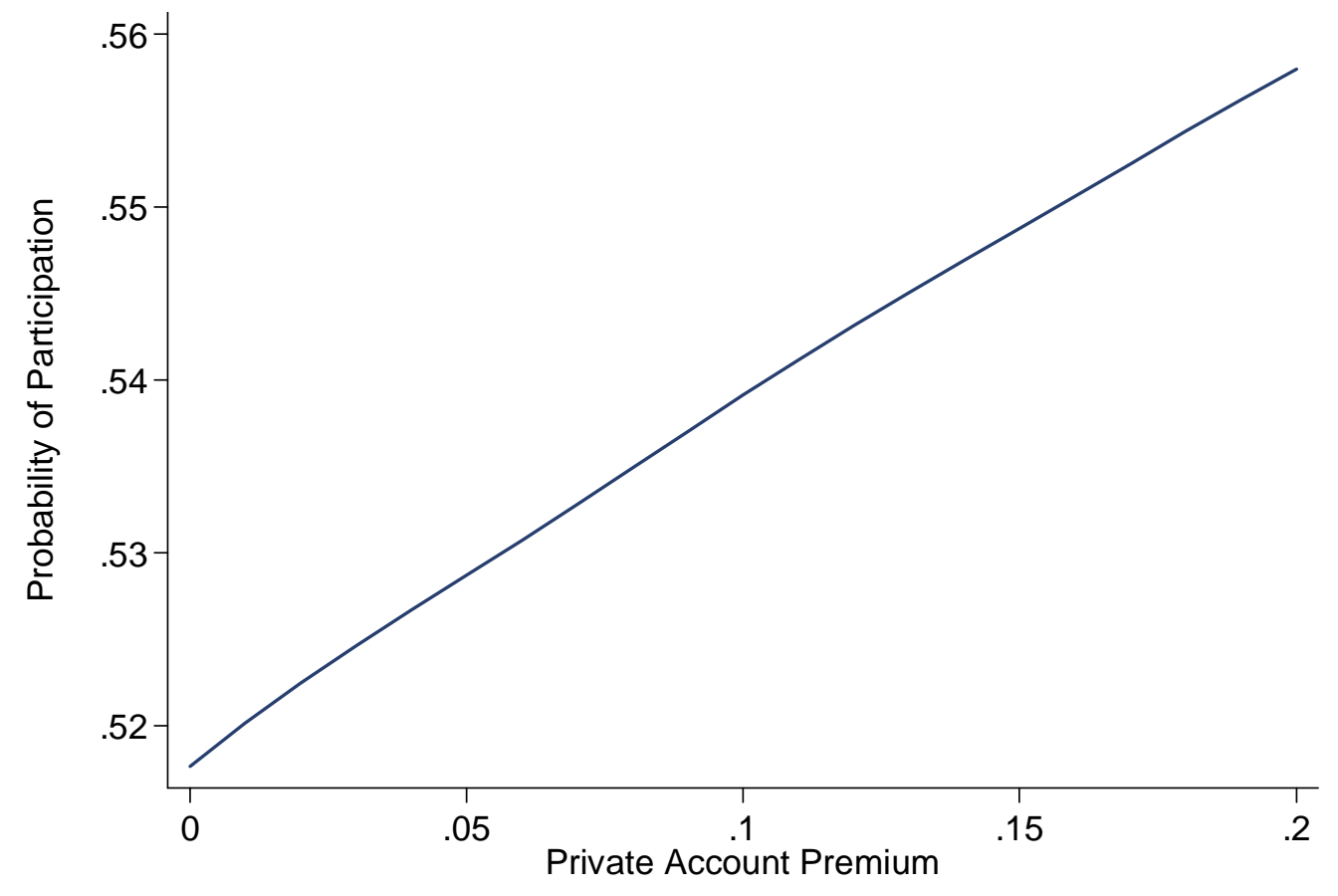


Figure 3. Impact of Account Premium on Aggregate

Participation by Age Category

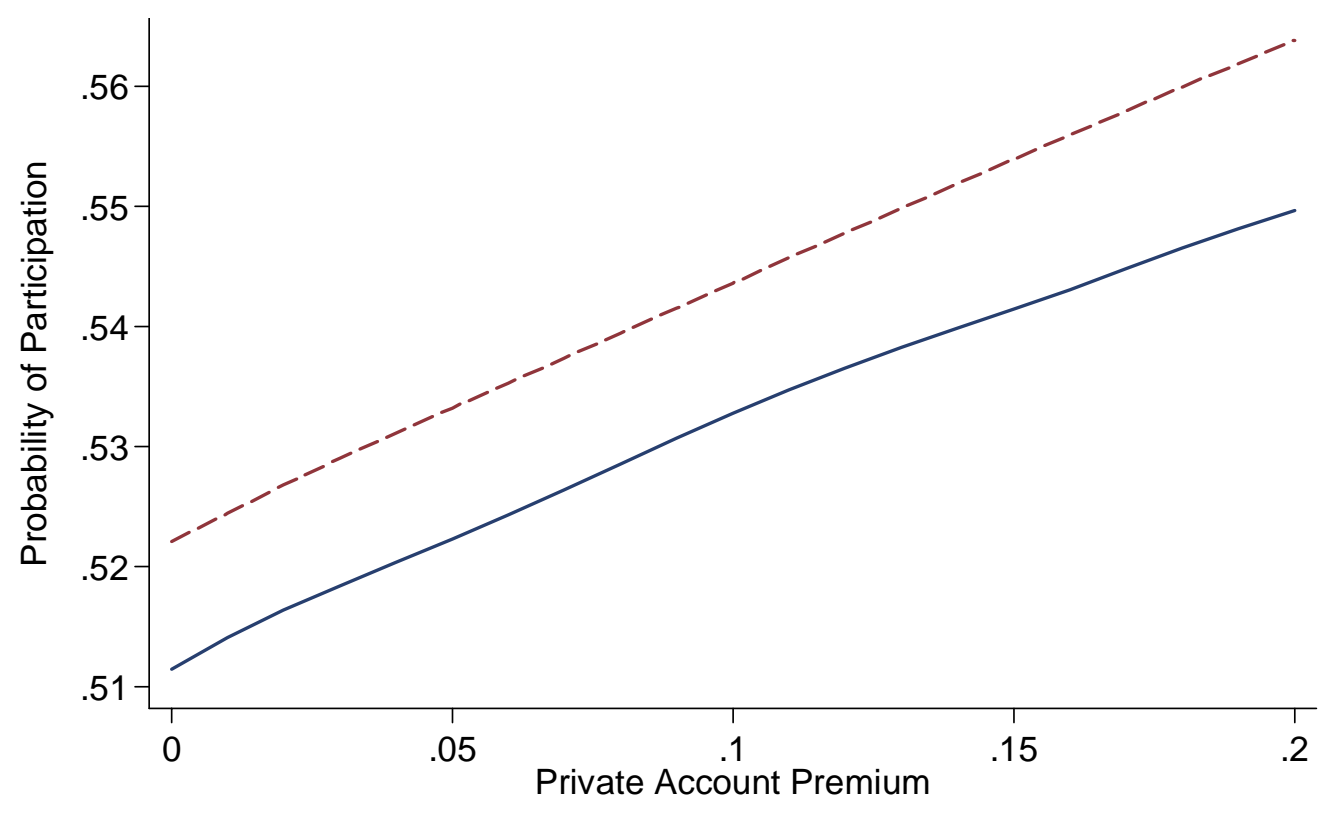

Age under 55 - - - - Age 55 and over 
Figure 4. Impact of Account Premium on Aggregate Participation by Education Category

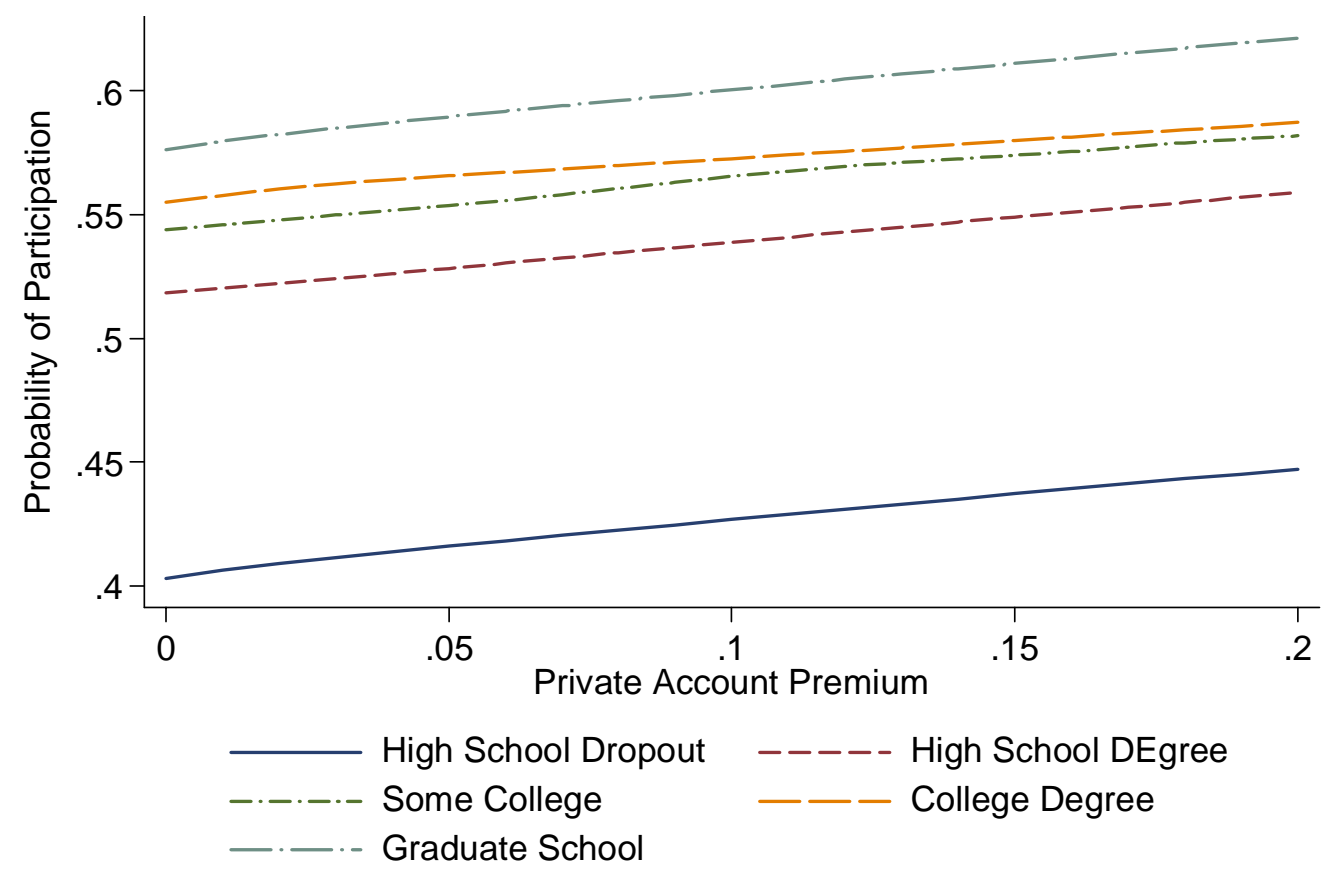


Figure 5. Impact of Account Premium on Aggregate

Participation by Race

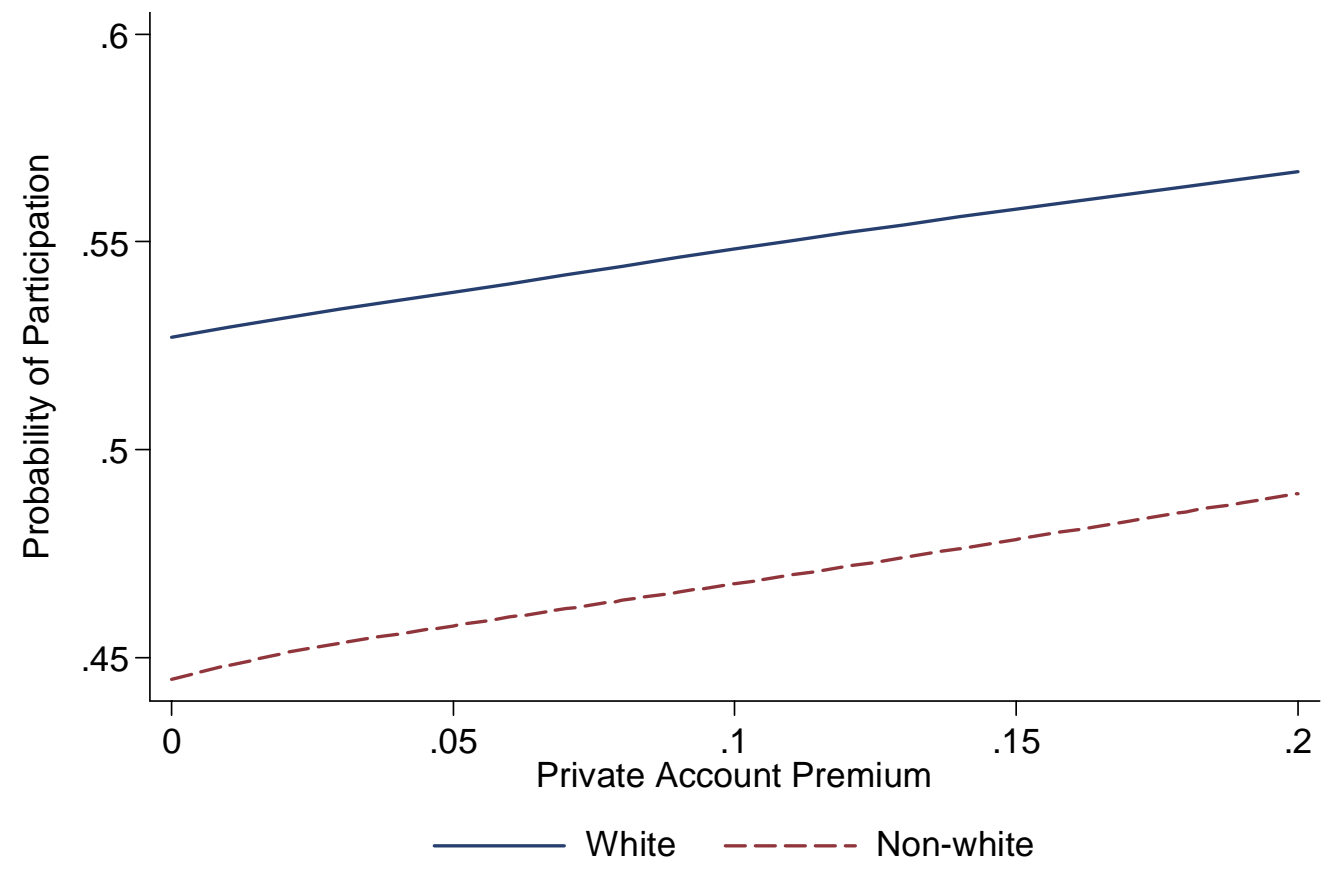


Figure 6. Impact of Account Premium on Aggregate

Participation by Marital Status

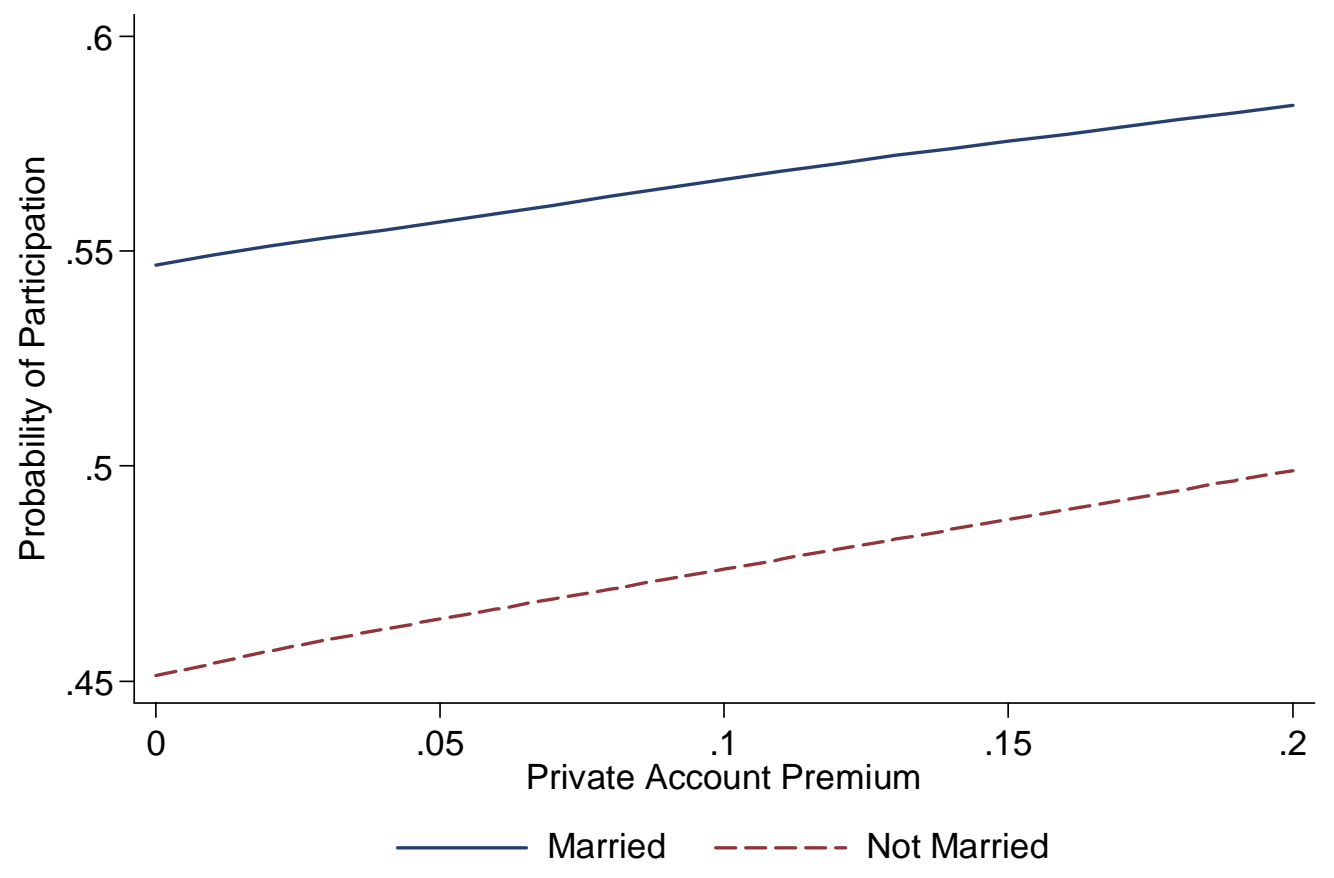


Figure 7. Impact of Account Premium on Aggregate

Participation by Sex

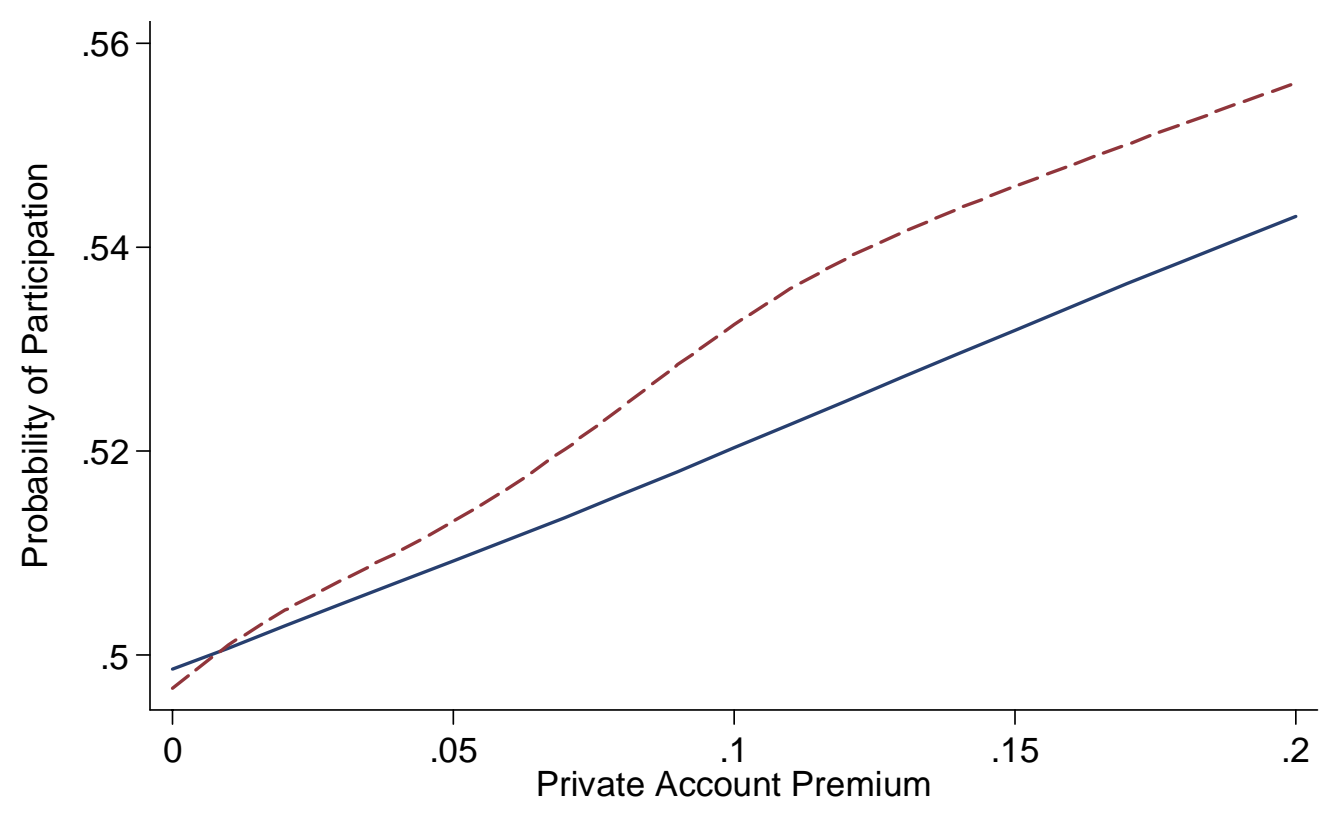

Male - - - - Female 
Figure 8. Impact of Account Premium on Aggregate

Participation by Type of Private-Pension Coverage

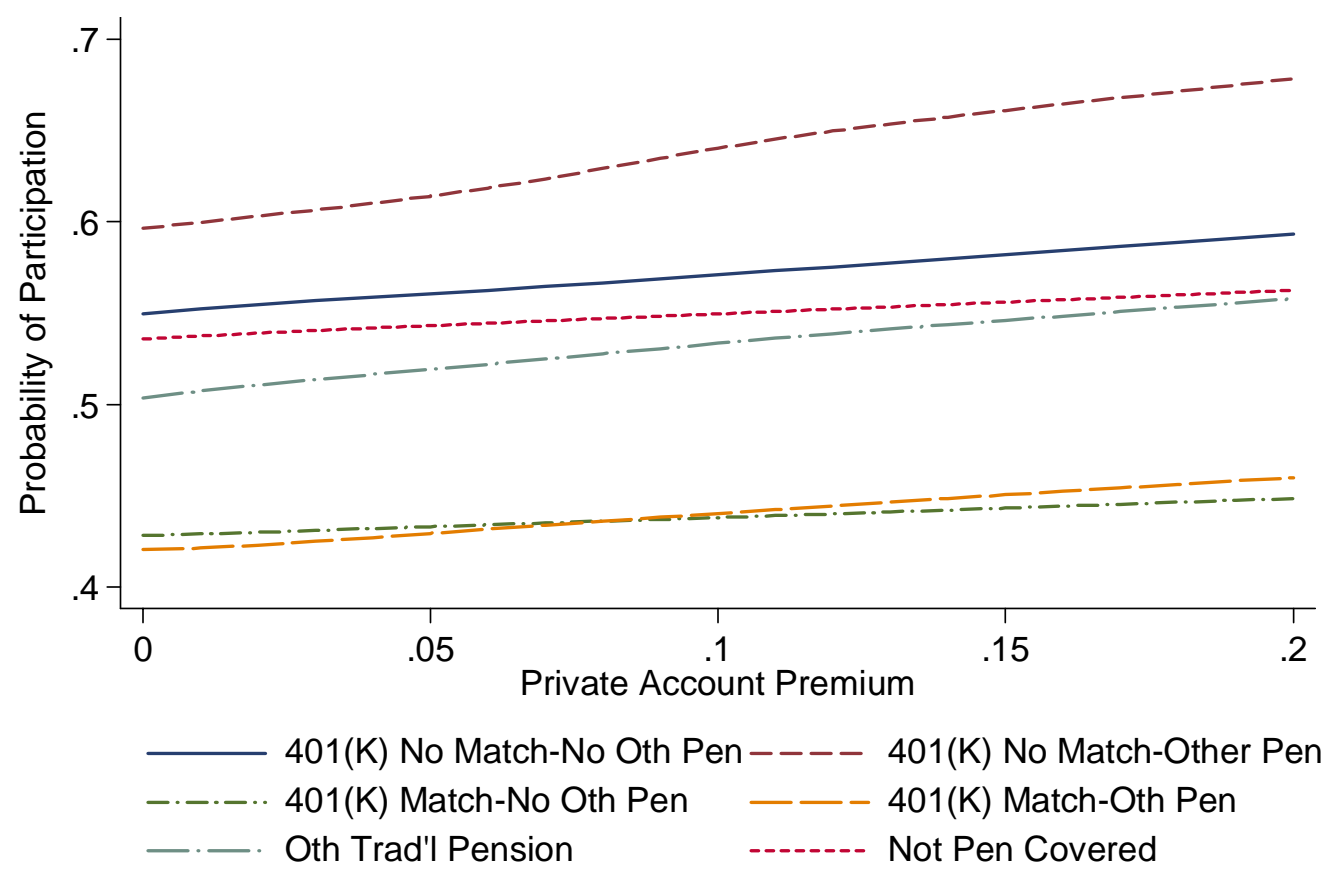




\section{RECENT WORKING PAPERS FROM THE \\ CENTER FOR RETIREMENT ResearCH AT Boston College}

Social Security Personal-Account Participation with Government Matching

Gary V. Engelhardt and Anil Kumar, October 2004

Providing Guarantees in Social Security

Karen E. Smith, C. Eugene Steuerle, and Pablo Montagnes, August 2004

Deferring Income in Employer-Sponsored Retirement Plans: The Dynamics of Participant Contributions

Karen E. Smith, Richard W. Johnson, and Leslie A. Muller, August 2004

Reform Model Two of the President's Commission to Strengthen Social Security: Distributional Outcomes Under Different Economic and Behavioral Assumptions Melissa M. Favreault, Joshua H. Goldwyn, Karen E. Smith, Lawrence H. Thompson, Cori E. Uccello, and Sheila R. Zedlewski, August 2004

An Analysis of How Individuals React to Market Returns in One 401(k) Plan Julie Agnew, April 2004

The Effects of Health Insurance and Self-Insurance on Retirement Behavior Eric French and John Bailey Jones, April 2004

Valuing Assets in Retirement Saving Accounts

James M. Poterba, April 2004

Lifetime Earnings, Social Security Benefits, and the Adequacy of Retirement Wealth Accumulation

Eric M. Engen, William G. Gale, and Cori Uccello, April 2004

The Effect of Social Security on Divorce and Remarriage Behavior Stacy Dickert-Conlin and Cristian Meghea, April 2004

Household Demand for Variable Annuities

Jeffrey R. Brown and James M. Poterba, March 2004

Lessons for an Aging Society: The Political Sustainability of Social Security Systems Vincenzo Galasso and Paola Profeta, March 2004

All working papers are available on the Center for Retirement Research website (http://www.bc.edu/crr) and can be requested by e-mail (crr@bc.edu) or phone (617-552-1762). 